\title{
The Discussion about the Reform of English Teaching Methods of Reflective Teaching Model
}

\author{
DENG Lianmei ${ }^{1, \text { a }}$ \\ ${ }^{1}$ Chongqing College of Finance and Economics, Chongqing 402160, China \\ adenglianmei@126.com
}

Keywords: Reflective teaching, College English, reform, application

\begin{abstract}
Practice and reform of English teaching methods in Colleges and universities has been a major issue in academic research and discussion. In 1990s, domestic scholars began to reflect on the theory of teaching research and practice, in order to explore the reform of teaching methods in higher education, to train qualified personnel in line with the requirements of the times. On the basis of research and practice in Higher Vocational English Teaching in Colleges and universities, the application problems in Higher Vocational English teaching and reflective teaching method in College English teaching reform, in order to provide research and practice of teaching methods to provide some material for scholars "'".
\end{abstract}

\section{The Idea of English Teaching in Colleges and Universities}

What is the core concept of College English teaching? This is the primary problem that must be made clear to every educator who is engaged in the theoretical research and practice teaching of College english. College English should not be treated in narrow sense. The solution is "in Institutions of higher education in English education and learning, English Teaching in primary and middle school and it is essentially different, which is mainly embodied in it is no longer simply teaching vocabulary and grammar to the basic knowledge of English education, but pay more attention to the ability to develop and cultivate their English Comprehensive application, i.e. to enhance college students listening and speaking, reading and writing and translation ability, so that they can have their familiar topic with English accurate understanding and correct expression and freedom of communication, so as to better meet the needs of the society. Therefore, the main purpose of College English teaching should be to cultivate the ability of learners to master and use English, rather than to simplify English into a single knowledge". Unfortunately, many domestic colleges and universities do not truly understand the essence of English Teaching in Colleges and universities, is still a continuation of "heavy knowledge and light ability" teaching mode, the teaching effect also has no substantive change. Therefore, in the classroom of College English, what we still see is that educators are always trying to explain the meaning, analyze the sentences and translate the text..... To improve the education of English listening and speaking ability and use requirements of the deaf. All this is a misreading of the core concept of College English teaching, if not timely change the old teaching idea, the teaching of College English to achieve better and faster development, is the only castles in the air. The concept of College English teaching reform, the English teaching is to cater to the examination requirements, pay attention to the examination results, ignore the comprehensive application ability of the educated English improved, based on the actual English level into the educated as the starting point, to stimulate the pedagogue's interest in learning English as a driving force, its goal is to educated English proficiency levels, there are steps to carry out new forms, rich content, strong participation, interactive strong English teaching practice, and effectively improve the English education and application ability, the time value of the real highlight of College English education. English teaching concept, as a qualified junior high school English teacher, first of all to understand the teaching concept of English, that is, what is the goal of junior high school English, why to set up English Teaching in junior high school?. English 
opening is not only to let students accept English Teaching in primary school English, but based on the deeper level to understand learning English, at the same time, for the day after the students in a higher teaching level in a good way, to lay a good foundation in English learning. It is mainly reflected in the comprehensive English ability and literacy of students, a comprehensive method to improve students' English learning, including the students' listening ability, writing ability, reading ability and other aspects of comprehensive training. Let the students for a topic to develop accurate and fluent in English communication and discussion. It can be seen that English classroom teaching is more emphasis on the cultivation of students' English ability and the application of English ability, rather than simply give students a "indoctrination", passively let students learn knowledge. However, at present in many domestic English teaching are not good grasp of reasonable teaching methods, is still only to the students "indoctrination" classroom knowledge, let the student carry on the analysis, a simple sentence to recite the words, text translation, is still attach great importance to the cultivation of student's knowledge, ignoring students' ability the English Teaching in China has greatly improved.

\section{Reflective teaching and Its Characteristics}

Reflective teaching is a teaching theory and method formed on the basis of continuous exploration and research of reflection. The academic circles believe that the first truly systematic exposition of the relationship between education and reflection is the American educator John Dewey. In China, the theoretical and practical research on reflective teaching arose in the late 1990, and has become a focus in the field of educational research. Definition of the connotation of the scholars is Different people, different views. Xiong Chuan Wu (1999) believes that the "reflective teaching action research with teaching subjects, and constantly explore and resolve its teaching goals and teaching methods and other aspects of the problem," learn to teach "and" learning to learn "together, strive to enhance the rationality of teaching practice, make oneself become a scholar type teacher." Zhang Lichang (2001) argues that reflective teaching refers to the teachers in the teaching practice, critically examines the behavior of self-expression and its basis, through the review and diagnosis, self-monitoring, or affirmed and strengthened, or deny and amend to continuously improve their teaching effectiveness and high quality." In general, the following characteristics: reflective teaching, reflective teaching has a purpose. In the process of teaching, the purpose of teacher reflection is to improve teaching methods and improve the quality of teaching, which is the main channel for teaching to explore the inherent law of teaching. Many educational theorists and practitioners believe that reflective teaching is put into practice and become one of the main reasons for the current mainstream teaching theory is a kind of "people usually assume that reflective teaching and teacher education is good and reasonable in nature, and more teachers can reflect, in some sense, the more good teachers". When people strive for rationality and confirm ideas and actions to form a new understanding and appreciation of phenomena, teachers should encourage teachers to carry out reflective teaching." Reflective teaching is systematic. Reflective teaching is a systematic project for teachers to participate in teaching and learning. It requires teachers to realize "self-study" and "learning", so as to achieve the goal and value of teaching. From the point of view of this layer of meaning, reflective teaching requires teachers to teach students to learn how to learn and master the knowledge, students' comprehensive quality, but also requires teachers to learn teaching, improve teachers' theoretical level, truly become a beacon of students to explore knowledge palace "'. Therefore, the reflective teacher and experienced teachers are different. Experienced teachers pay more attention to their teaching results in the teaching process and results; and reflective teachers are not simply in the teaching results to measure teaching performance, but also on the results and the inducement of inner relation factors are analyzed, always bring problems to teaching, often expressed as a "why" consciousness. This kind of "questioning" habits often prompted reflective teachers to enhance awareness of the problem and problem-solving ability. Reflective teaching is innovative. Reflective teaching is not an "indoctrination" one-way knowledge transfer, it is an innovative teaching activity. Specific performance: (1) as a kind of teaching activity, reflective teaching of "reflection" is a kind of teaching experience beyond the teaching summary or 
simple reflection on teaching reflection, reflection is a repeatable experimental research significance. As a kind of teaching activity, reflective teaching method based on the combination of science and humanities, creative "better" to complete the task of teaching, better annotation in decision making and technology and ethical aspects of teaching the teaching subject, teaching objectives and teaching tools and other aspects of the problem. In a word, in the reflective teaching, teachers can get the opportunity to think creatively, and also get creative opportunities to solve problems. Reflective teaching has autonomy. Reflective teaching pays more attention to the cultivation of master's attitude in teaching, which focuses on enhancing teachers' moral sense; paying more attention to the cultivation of teachers' thinking ability, so as to improve the quality of Teachers

The ability of multiple integration and transformation between theory and practice. Generally speaking, unless the teaching errors or teaching inspection and teaching observation are driven by the external pressure of teachers, the teachers without moral sense will not consciously oppose it

Reflective teaching behavior. Theoretical research and practice proves that universities should fully reflect the function of personnel training, improve the quality of teaching, enhance teachers' morality seems to further improve the ratio of the teacher's teaching skill is more important. Reflective teaching is one of the effective ways of teachers' moral sense and a sense of responsibility to enhance.

\section{The Practice of Reflective Teaching in English Teaching in Higher Vocational Education}

The present situation of English Teaching in Higher Vocational colleges. The knowledge reserve of vocational college students is relatively weak. Since the expansion of college enrollment, more students realize the university dream through the college entrance examination, and thus change the trajectory of life. As for the whole country, the continuous growth of higher education makes the national quality generally improved. However, because of their own knowledge and regional differences and the shortage of teachers and other subjective and objective factors, compared with undergraduate students, vocational students both the enterprising spirit of learning attitude, learning methods and ability is relatively poor. As far as English majors are concerned, the basis of students is generally poor, and the mastery of grammar knowledge is not systematic and solid. The vocabulary is generally less and the listening and speaking ability is weak. English is generally expressed as a "do not understand can understand the" dumb "english. Therefore, a lot of students for English learning, generally showing a dynamic and negative emotions, learning enthusiasm is not strong, active participation in teaching, interactive consciousness is not high. In the course of time, the students in learning English from the beginning on the concept of indifference and conflict to finally "pay for the action, skipping as a bad" choice "in English learning of higher vocational students, it brings some difficulties and challenges to English Teaching in Higher Vocational colleges. Teaching facilities is relatively backward, the teaching mode is too old. First of all, due to the domination of the education law and the restriction of teaching cost, the expansion of the enrollment scale of colleges and universities has led to the large class teaching in many colleges and universities, as well as the higher vocational education. Although English teaching is still in the natural class, but also in the general number of at least 33 people, more than seventy or eighty people, even hundreds of people, which adapt to the language classroom teaching activities and methods of implementation cannot be normal. In addition, higher vocational students English teaching facilities is relatively backward. Secondly, in the existing education system of our country, University Teachers' reputation, influence and promotion, the promotion is more through its scientific research strength and level to measure and assessment in the real interest drive, more teachers spend more time and energy to focus on scientific research, rather than teaching. The pressure of scientific research causes the teachers not to take into account the renewal of teaching ideas, and cannot reflect on the implementation of the new teaching mode. From the teaching process, teachers mainly focus on the interpretation of textbook knowledge; the teaching methods are too single, the formal procedure is more important than the substantive content. In class, students are only passive receivers of knowledge, and almost no or only a little time to get the true meaning of knowledge exchange and interaction. Therefore, the completion of the teaching task 
under the provisions of the "What I say goes." and "base" teaching method ignores students' practical application of language ability, is not conducive to develop students' independent thinking ability and shape innovation ability.

\section{The Enlightenment of Reflective Teaching in English Teaching}

Reflection on the practice of reflective teaching in English Teaching in vocational colleges, summed up the following enlightenment from them, in order to offer some thoughts on further exploration of the reform of Vocational English teaching methods, English teachers should have the knowledge of lead. Sue Home Linsky said: everyone is the one and only in the world. Then, the teacher wants to give students a scientific theoretical system, to lead the students to become a beacon of "the other", which is important for teachers to master the system of scientific knowledge system, which requires teachers to constantly improve their own quality and strengthen the theoretical knowledge of the update. Teachers in the teaching practice, according to continuously update the teaching idea and teaching beliefs of the actual need, update teaching knowledge and teaching skills, which can really guide students to the temple of knowledge, in order to truly meet the changing needs of teaching, in order to adapt to the modern diversified teaching mode, improve the quality of teaching. The design of teaching activities should be reasonable. In order to design the teaching activities and effectively implement teaching activities, from the different angle of the main body of reflective teaching behavior, teachers should teach and theoretical perspectives, such as student perspective, peer perspective. This process will help teachers optimize teaching design constantly, and make classroom teaching achieve the desired effect. Reflection on teaching and learning from the theoretical perspective can encourage teachers to break the existing scope of knowledge, help teachers to express unique beliefs, knowledge and ideas; reflection in the students or between students and teachers make teaching more suitable for students of different learning methods and learning preference from the perspective of the students, to achieve the interaction of teaching and learning; reflection from the perspective of Tongren can gather effective teaching methods and effective to solve the problems and problems in teaching. The total, higher vocational English teaching requires teachers to scientific, reasonable and effective design and arrangement of each teaching step in the implementation of teaching activities, stimulate students' interest and learning ability, finally achieve the purpose of improving the teaching quality. Classroom teaching methods should be diversified.

\section{Conclusion}

With the development of society, the teaching reform is also deepening; the reform and practice of College English teaching methods have always been the important content of the teaching reform in Colleges and universities. Since 80s, reflective teaching has developed rapidly in some western developed countries, and has become the ideological trend of educational reform. In recent years, China's educational circles have also discussed the reflective teaching, but the implementation effect is not very ideal. Therefore, strengthening the study of reflective teaching is of great significance to promote the reform of College English teaching methods. The connotation of reflective teaching, the connotation and characteristic analysis of 1 . reflective teaching. Reflective teaching (called reflective teaching), refers to teachers in the implementation of the process of teaching, in teaching under the guidance of advanced theory, by means of action and Research on their teaching, continuous reflection, and according to the problems existing in the teaching of active exploration, to solve the problems existing in the teaching of their own in. The unity of learning and learning to make their own teaching practice more reasonable, at the same time teaching, but also to do a good job in learning. Reflective teaching is called reflective teaching or reflection of professor. 2. Analysis of the characteristics of reflective teaching. Reflective teaching is an advanced teaching theory and teaching method, has its unique characteristics. First of all, reflective teaching has a strong purpose. The purpose of teachers' reflective teaching is to improve teaching methods and improve teaching quality. Secondly, reflective teaching has strong 
autonomy. The liberation of the teachers, put more time to the students, teachers take observers and assist in the identity; and also gave the teacher a bigger challenge: to speak little, and to reach the teaching goal, not only to explore; give students greater freedom, but also to ensure the classroom order is maintained.

\section{References}

[1] W.Y. How to enhance the core value of Chinese national brand. Business research, 2013.

[2] Y. X ,S.Q. P. The influencing factors of consumer brand relationship: an explorationSex studies. Business research, 2012.

[3] Y.F.C , Y.P.Q. Customer retention and its influencing factors from the perspective of relationship marketingElement analysis, 2010

[4] Ma Yingshuang, Zhang Haomin: "analysis" the relationship between customer satisfaction and customer loyalty.Enterprises, 2010

[5] L.L. Research on the promotion strategy of customer value from the perspective of brand relationship

Industry, technology and economy, 2009The background and research background of brand relationship management under the customer perspective from [6], Shanxi, Shanxi and so onStatus quo, 2008 